ミックレンジの狭さとブルーミング効果の改善も大きな 課題である. 最近 CCD カメラの登場で, ある程度は改良 されていると考えているが・..

3） TVカメラノイズと装置のシステムノイズ (電気的) 低減も重要な課題である.

4）診断可能な DR 画像の画素数 $\cdots 1 \mathrm{~K}, 2 \mathrm{~K}$ マトリスク (各圧縮画像含)の選択はデジタル画像の付加価值を考え れば画像情報は少ない方が，画質を考えれば多い方が良 い. しかし根本的に1)，2，3）の問題が改善されないと, $2 \mathrm{~K}$ マトリスクにして本当に意味があるだろうか？自 分は現状では $1 K$ マトリスク (圧縮画像) で充分と考えて いる.

- 画像処理

リアルタイムで診断上必要な全画像を CRT上に最適 画像で表示することは現状では難しい. 手間と時間をか けポストプロセッシングで行なうのが現状である。

次に，放射線画像を全面デジタル化にする，その有用 性すなわち付加価值を考えてみたい.

1) PACS, HIS, RIS 等すなわちフィルムレス化

2）医療体制の見直しと保険診療体制の合理化

3）国民の医療被儤線量の低減 等が考えられる.しか し画像を全面デジタル化するには経済性, 作業時間, 保 険点数 (現時点); 国家的コンセサンス, 医療情報のセキ ュリティーおよび互換性（圧縮画像）等問題が山積して いる.しかし将来的には消化管撮影はスクリーントフィ ルムから I.I./DR に移行するのは間違いないと考えてい る.

以上, 発表の要旨と私見を述べた。

\section{DR-6 画像評価（演題番号424～427）}

三原一博（大阪府立病院）

このセッションは，DR の中でも $\mathrm{CR}$ を取り上げてい る. 4 題の内 3 題は撮影条件汇関するもの, 残りの 1 題 は EDR に関するものであった。演題424は, 胸部断層撮 影における適正な管電圧を決定しょうとする試みであっ た. 実験は管電圧を $80 \mathrm{kV}$ から $120 \mathrm{kV}$ まで変化させて撮 影した臨床像について, 解剖学的に異なる部位に分け, それぞれについて主観的な方法で 5 段階評価を行ってい た.結果として肋骨近傍の血管影を除いては, $80 \mathrm{kV}$ が良 かったとしている．しかし，好みで判定されがちな今回 のような評価方法でいきなり結論を導くことは，以下に 示す質問からも伺えるように，もしも結果が正しいとし ても疑問が残る。

質問 CR では，線質の変化に対し画像はどのように
変化すると考えておられるか. 結果に対しては, 納得の 行く裏付けを示していただきたい. 小寺（近畿大学）

演題425では, 頭部神経ブロック撮影における適正な撮 影条件を得る試みであった。診断，治療目的に何を描出 すべきかを最初に明記して, 基礎笑験から臨床評洒へと 実験が進められている．さらに，基礎データと臨床結果 とのつながりについてもよく考察がなされていた。ただ， 総会当日の報告では線量が明記されず，相対值にとどめ られていたのが残念であった。予稿集では線量が加筆さ れているので是非参考にされるとよい(ただし，Gyで表 示されている).

質問 周波数処理におけるノイズの検討はされている 加. 吉沢 (関東聥信)

答 今回は，線量低減の検討にとどめた。

演題426は, 腹部について㟝断目的に応じた適正な線量 を，腹厚，年齢別に対して求める試みであった。撮影部 位, 撮影目的に応じて適正な線量を科学的に証明するこ とは大変困難である. 以前から演者らは, 撮影部位, 撮 影目的等に応じて用いる線量は異なるということを提唱 している.CRに扔ける適正線量は, その画質が䛦断に影 響を及归さない最低線量であるという考えを基に, 独自 の方法で CR における被曝低減の一連の研究がなされて 来た.このことに対し敬意を表する. しかし, 演題424で も述べたが，何故このような結果が得られたのかに対す る根拠に乏しい. 特に, 以下の質問に対しては，私も同 感である。

質問 年齢別評価は腹厚一定で行われたか。また，年 齢別で評価が分かれた原因について，体形等の考察はな されたか，渡辺（愛知，南生協病院）

答 腹厚は $2 \mathrm{~cm}$ の誤差の範囲内で限定した。体形に 対する考察は行っていない.

演題427は, 胸部断層撮影における EDR の安定性につ いての報告であった，特に演者は，S值は被曝線量の絶 対値では無いことを強調された，当施設においても，同 一線量を与えたにもかかわらず裁断面が異なると， S 值, L值, 画像濃度が異なることをよく経験する。しかし, $\mathrm{S}$ 值の意味をよく理解しているならば，私は線量管理を 行う上での目安になり得ると考元ている.

DR-7 CR 臨床応用他（演題番号428～433）

大石茂雄（愛媛大学医学部附属病院）

このセッションは，CR 臨床応用他としてまとめられ た 6 題であった。折しも本学会では, 機器展示として第 4 世代の CR システム (CR9000) がプレゼンテーション 